\title{
TRACING THE HISTORY OF IBĀDII LAW AND JURISPRUDENCE
}

\author{
Ersilia Francesca \\ University of Naples "L'Orientale"
}

\begin{abstract}
In this essay, Ersilia Francesca reviews scholarship on Ibāḍ̄ law, an understudied and marginalized subfield of Islamic legal history. She argues that recent scholarship in Ibạ̄̂̄ law has demonstrated that Schact was mistaken to dismiss Ibā $\bar{d} \bar{l}$ jurists as outliers who adopted Sunnī legal norms with only a few tweaks. To the contrary, studying Ibạdī law as a view of Islam "from the edge," she contends, enables a fuller picture of the multi-faceted process of Islamic law's emergence. She further offers a periodization for the study of Ibā $\bar{d} \bar{l}$ jurisprudence in three chronological stages: a formative stage in Basra, an intermediate stage generated by Ibā $\bar{l} \bar{\imath}$ travels to Oman and the Magreb, ending in "a stage of maturity."
\end{abstract}


$I^{2}$ badism still remains the most disacknowledged and misunderstood branch of Islam. In particular the Ibādī contribution to the field of law and jurisprudence is mainly underestimated within mainstream Islamic studies, which privileges Sunnī and Shī ite sources. However, studies on Ibadism have advanced in the last decades, thanks to the sustained efforts of researchers, associations (such as Ibadica in Paris), and the Ministries of Awqaf and Religious Affairs and Culture and Heritage in Oman. Studies on Ibāḍi law were first carried out during the European colonial period in Africa and in the Middle East when French (A. Imbert, M. Morand, M. Mercier, E. Zeys) and German (E. Sachau) scholars began to examine the legal works of the Ibādī communities in Algeria, East Africa, and Zanzibar. Their studies aimed at making the legal texts of the religious minorities available to the colonial rulers.

An academic reconstruction of Ibāḍi law was first attempted by Joseph Schacht in The Origins of Muhammadan Jurisprudence, ${ }^{1}$ a fundamental text for the study of Islamic law that has stirred up a great deal of controversy since its publication. Schacht starts with the assumption that the Sunnī schools do not differ from the Khārijite and the Shī' ite, any more than the latter two differ from each other. He affirms that the ancient sects, during the first centuries of Islam, were in contact with the orthodox community and merely adopted the Islamic law already developed in the Sunnī schools of law. In his account, they merely introduced marginal modifications intended to adapt it to their own political agendas and dogma.

Schacht's position on Khārijī/Ibāộ̄ law was challenged by several scholars. In his study on Ibāọī ritual purity, based on Kitāb al-wad' fí 'l-fur"̄' by al-Jannāwunī (Jabal Nafūsa, first half of the twelfth century), R. Rubinacci contests Schacht's assumption that the Khārijites merely adopted the legal system of the orthodox schools. ${ }^{2}$ On the contrary, he argues that the Khārijites played a significant role in developing Islamic law,

1 J. Schacht, The Origins of Muhammadan Jurisprudence (Oxford: Clarendon Press, 1950), 260-61 (Chapter 8 on Khärijī Law).

2 R. Rubinacci, "La purità rituale secondo gli Ibāḍiti," in Annali dell'Istituto Universitario Orientale T1957, 1-41. 
as they were driven by a particularly strict ethical code that was kindled by an intense, on occasion exaggerated, religiosity.

In 1971, 'Amr Khalīfa Ennami (al-Nāmī) defended his $\mathrm{Ph} . \mathrm{D}$. thesis at Cambridge University entitled Studies in Ibādism, which can be considered a milestone in research on Ibāḍi dogma and law. In the chapter on jurisprudence, he confutes Schacht's theory on the late derivation of Ibādī law compared to the Sunnī schools by showing that the Ibādīs contributed to the process of the formation of Islamic law, developing their own legal system that was differentiated from the Sunnī system in many ways. Ennami's study is based on his own research on Ibādī manuscripts, which led him to study works scholars had not previously consulted from the first centuries that . Therefore, Ennami could demonstrate that the Ibāịīs began to draw up their own legal treatises at the same time as the ancient schools of law, or even earlier.

Following Ennami's works, further studies carried out by J. Wilkinson, E. Francesca, A. al-Salimi, A. Gaiser, M. Muranyi, demonstrated that the Ibādīis set forth, from the beginning, an independent line from the Sunnī schools, with autonomous authorities and jurists. They developed a rich literary heritage stretching back to the formative period, which is of great potential importance. In particular, research focusing on Ibāọi law in the first centuries of Islam can contribute to offering tentative solutions to the main problems concerning the formative period of Islamic law, such as questions concerning transmission, authorship, and content.

As far as the development of the Ibāḍi school is concerned, Wilkinson refers to a process of "normalization" or "hadithication" through which Ibāḍīs rationalized the development of their school. They identified Jābir b. Zayd (d. between 711-12 and 722-23) along with his Meccan connections as the founding figure and stressed the master-pupil connection among the first leaders of the Basran community (Jābir, Abū 'Ubayda, al-Rabī') for the transmission of knowledge (hamal or raf' al-' $\mathrm{ilm}$ ) in the same way as the "imamate" of the community passed along this 
same line. ${ }^{3}$

In recent years, the critical editions of rasā'il, 'aqīda, fiqh books, and other Ibāọī sources by Ennami, A. al-Salimi, W. Madelung, F. Ja 'biri, among others, have made valuable material available to researchers. ${ }^{4}$ Custer's catalogue of the Ibādī primary and secondary literature shows the richness of the Ibādī literary heritage, which has only been partially explored. ${ }^{5}$ The annual series of International Conferences on Ibadism, which started in 2009 in Thessaloniki, have further expanded the field and attracted new scholars to Ibāọī studies. Among the Conference proceedings published by OLMS in Germany, the volume on Ibādî jurisprudence provides a comprehensive framework for the study of Ibāọī law. ${ }^{6}$

\section{THE DEVELOPMENT OF IBĀḌī LAW AND JURISPRUDENCE:} A Periodization

In my research, I mainly focused on the early development of Ibāọi law and jurisprudence. I suggest that looking at Islam from the edge can provide us with a better understanding of the entire formative process of Islamic law. The themes treated in early Ibāḍi sources reflect the legal debates taking place during the first centuries of Islam, reflecting two opposing trends which may be identified in the formative phase of Islamic law: the continuation of local legal traditions and the efforts of

3 The early development of the Ibādī school is summarized in J. C. Wilkinson, Ibādism. Origins and Early Development in Oman (New York: Oxford University Press, 2010), 122-210.

4 In the 70s Ennami edited the Ajwibat Ibn Khalfün (Beirut, 1974) by the famous scholar Abū Ya'qūb Yūsuf Ibn Khalfūn al-Mazzātīl-6th/12 th century), providing impetus for the publication of Ibādī works. For the most recent editions of early Ibādī sources, see, e.g.,A. Al-Salimi, Early Islamic Law in Basra in the 2nd/8th Century: Aqwal Qatada B. Di'ama Al-Sadusi (Leiden: Brill, 2018); A. Al-Salimi and W. Madelung, Ibāḍī Texts from the 2nd/8th Century (Leiden: Brill, 2018); F. alJa 'bīrī, Rasā'il al-Imām Jābir b. Zayd (Oman: Maktabat al-Ḍāmirī li-1-Nashr wa-'lTawzī' ${ }^{\prime}$ 2013).

5 M. H. Custers, Al-Ibādiyya: A Bibliography, 2nd ed. (Hildesheim: Georg Olms Verlag, 2017).

$6 \quad$ B. Michalak-Pikulska and R. Eisener, eds., Ibadi Jurisprudence: Origins, developments and cases (Hildesheim: Georg Olms Verlag, 2015). 
the first jurists to find solutions which conform to Islam.

As far as the dynamic between Islam and late antiquity is concerned, I scrutinize the interactions between different and concurring legal praxes, focusing on the consistency and plausibility of the ongoing narrative and ikhtiläf on zina as an impediment to marriage in Ibāọī law. ${ }^{7}$ I argue that a plausible answer to the question of the relationship between Islamic law and other legal systems, as in the case of adultery and fornication, can be found in the common cultural and social background they shared, which refracted through the Jewish and Christian legal traditions down to the eve of the rise of Islam.

As Muslim legal actors gradually relied upon an increasing number of textual sources for legal opinions, they incrementally gained their own interpretive autonomy. Examining pre-classical and "non-orthodox" legal collections - such as early Ibāḍī texts - along with their relationship to non-Islamic sources, is a fruitful method for depicting the multi-faceted process of the early formation of Islamic law.

In my research, I outline three different stages in the development of Ibāộ̄ law and jurisprudence: a formative stage in Basra, an intermediate stage when the communities moved to Oman and the Maghreb, and a stage of maturity in both Maghreb and Oman.

In the formative stage (approximately mid first/seventh-third/ninth century), Ibādī jurists were in contact with the Sunnī community and they acknowledged the authority of Sunnī traditionists, such as Qatāda b. Di' āma, ' 'Amr b. Harim, 'Amr b. Dīnār, Tamīm b. Khuwayṣ, and 'Umāra b. Hayyān. In this period, a number of doctrines, diverging from Sunnī law, emerged in Ibāọi law. For example, the rejection of mash 'alā 'l-khuffayn (wiping shoes instead of washing feet as part of ablution), the injunction that the property of a client (mawlā) who has no

7 Jerusalem Studies in Arabic and Islam, 49, 2020 (forthcoming).

8 A collection of traditions and opinion attributed to Qatāda along with those of early Ibāḍi authorities has been recently edited by al-Salimi under the title Early Islamic Law in Basra in the 2nd/8th Century: Aqwal Qatada B. Di 'ama Al-Sadusi (Leiden-Boston: Brill, 2018). This source is of crucial importance in understanding the relationship between Sunnīs and Ibāọīs in early Islam. 
relatives is to be inherited by his people and not by his patron, and the impediment to marriage between an unmarried man and an unmarried woman who have committed fornication, are all doctrines that differ between Ibāọī and Sunnī law.

Some traditions transmitted by old Ibāḍī jurists support doctrines rejected in later legal works. Typical of this group of "unsuccessful" traditions are those assuming that exchanges of precious metals involve no usury unless there is a time lag in the transaction (absolute equality in quantity is not demanded) and those allowing the sale of an umm al-walad or mudabbar slave.

The development of early Basran Ibādisism into a conventional madhhab was associated with an increasing consciousness of differentiated group identity. This is evidenced by the fact that the marriage between an Ibāḍī woman and a non-Ibāḍi man, although considered lawful, was nonetheless disapproved of. The validity of prayer performed behind a non-Ibāḍi imām was also discussed at length in early Ibādīi sources. Jābir b. Zayd was said to have performed the Friday prayer under the guidance of the Umayyad governor al-Hajjāj, but later scholars seem to have held that praying behind a non-Ibāội imām was invalid and had to be offered again. This dispute emerged in the correspondence between Abū Sufyān Maḥbūb b. al-Raḥ̄l and Hārūn b. alYamān, during the imamate of al-Muhannā b. Jayfar (841-852), and gave rise to the question of the true 'tradition' of the Ibādī Basran community.

The development of Ibadism as a movement in general and as a school of law in particular was mainly in the hands of the fuqaha ' and 'ulama $\bar{a}$ '. When the community was still based in Basra, the first Ibādī authorities were in close contact with Sunnī scholars, exchanging advice and opinions with them, thus contributing to the general development of Islamic law. When the community left Basra and settled mainly in Oman, Hadramawt, and the Maghreb, there was no rivalry between the main centers of Ibadism even though they developed chains of transmission (isnād) of their own comprising local authorities. There were transmitters who, having studied in one center, moved to another center and disseminated the learned material there ("bearers of 
knowledge', hamalat al-'ilm), so the bulk of traditions going back to early Ibāḍi Basran authorities became the 'common property' of the whole Ibādī community.

The fourth/tenth century marked a new phase (which we can call the "intermediate phase") in the development of Ibādī law with the expansion of works of ușūl and furü'. The development achieved by Ibāọī jurisprudence is clearly visible in the work of the Omani jurist Muhammad b. Sa'îd al-Kudami (who lived between the end of the fourth/tenth and the beginning of the fifth/eleventh centuries) entitled $a l-M u$ tabar. According to al-Kudamī, the sunna's main function (as well as that of the community's consensus, $i j m \bar{a}^{\prime}$ ) is interpreting God's Book. Judges and jurists have to rely on these three sources (Qur'ān, sunna, and ijma $\bar{a}^{\prime}$ ) in issuing their judgments or legal opinions. ${ }^{9}$ Along with al-Kudamī's treatise, the Kitāb al-jāmi ' by 'Abd Allāh b. Muhammad b. Baraka al-Bahlawī (d. late fourth/tenth century) became a fundamental reference point for Omani-Ibāḍi jurisprudence. ${ }^{10}$ This work made a notable contribution to Ibādī fiqh by affirming the centrality of prophetic traditions, which constitute the fundamentals (qawā id) of both jurisprudence and hermeneutics (ușül al-fiqh, which he calls $u s ̦ \bar{u} l$ al-dīn al-shar 'iyya). He was familiar with Sunnī sources, which he studied to affirm the superiority of the Ibāọī school against the "mukhālifün," or opponents, and introduced into Ibadism some elements of Sunnī hadīth classification."

Ibādīis find no problem with the traditions of other doctrines as long as their chains of transmission are trustworthy and there are no substantive reasons in the report not to accept them. Ibn Baraka said "we do not deny the traditions of others as long as they are not corrupt." ${ }^{12}$ This communal sunna was absorbed

9 Al-Kudamī, Abū Sa '̄id Muhammad b. Sa īèd, Kitāb al-Istiqāma, 3 vols. (Muscat: Wizārat al-Turāth al-Qawmī wa-'l-Thaqāfa, 1985), Vol. 3, 6-7.

10 Wizārat al-Turāth al-Qawmī wa 'l-Thaqāfa, ed., 2 vols (Sulțanat 'Umān, 1971, 1973).

11 Ibid. Vol. 1, 14-15 (al-Jāmi'; bāb al-awal fì 'l-akhbār). On hadīth classification see ibid. 16-21 (bāb fì 'l-akhbār al-murawiyya 'an al-nabì).

12 Quoted in Aḥmad Ibn Ḥammū Kurrūm, Ishāmāt al-madrasa al-Ibāạiyya fi khidma al-sunna al-nabawiyya (El Hamiz (Algeria): Markaz al-manār, 1432/2011), 13-15. 
into the Ibāḍi madhhab but only to emphasize certain desirable behaviors ( fadīla), never for determining dogma - for that Ibāḍi authority alone was valid.

The stage of maturity of the Ibādī law, along with the ongoing process of "hadithication," is evident in the works by the Omani encyclopedists at the end of the fifth/eleventh and the beginning of the sixth/twelfth centuries, in particular the Kitāb al-diy $\bar{a}^{\prime}$ by Salma b. Muslim al- 'Awtabī (d. early $6^{\text {th }} / 12^{\text {th }}$ cent.), the Bayān al-shar' by Muhammad b. Ibrāhīm al-Kindī (d. 508/1115) and the Mușannaf by Abū Bakr Aḥmad b. Mūsā alKindī (d. 557/1162). By the mid-twelfth century Muhammad b. Ibrāhīm al-Kindī collected the siyar, epistles on different matters of theology and jurisprudence written by early Ibāọī authorities, which played a crucial political and pedagogical role within the community. They constitute an instrument of legitimization of Ibāộ political and religious ideology and a guarantee of the collective cohesion.

In North Africa, after the definitive collapse of the Rustamid imamate following the victory of the Fatimids in 358/86869, the Ibādī community was forced to take refuge in the remote oases of the Algerian Mzab, on the island of Jerba, and in Jabal Nafūsa. There it managed to survive in secret (kitmān), led by a council of elders ( $a z z \bar{a} b a$ ). After the political collapse of the movement and a period of stasis, there was a new period of efflorescence in jurisprudence, parallel to that found in Oman. The process of maturity/hadithication in the Maghribi-Ibādī sources culminated in the first half of the sixth/twelfth century when Yūsuf al-Warjlānī completed his arrangement $(\operatorname{tar} t \bar{\imath} b)$ of a collection of hadīth attributed to al-Rabī' b. Habīb, in which traditions of the Prophet and the Companions were handed down through the imāms of the school, known as Musnad al-Rabi ' $b$. Habīb or al-Jāmi 'al-ṣaḥịh. For the Ibāḍ̄ madhhab the Musnad fulfills two important functions: providing an independent Ibāḍ̄ collection of hadīth without having to refer to other schools, and affirming the pupil-imām transmission line from the founder of the madhhab Jābir b. Zayd, via his successor Abū 'Ubayda, via the successor of the latter, al-Rabī' . 